\title{
PERANAN PERSON IN CHARGE DALAM PENYELENGGARAAN MICE DI BICC THE WESTIN RESORT
}

\author{
A.A. Sagung Amega Indra Theresa \\ I Wayan Suardana \\ I GPB. Sasrawan Mananda \\ Email : amegaindra@gmail.com \\ PS. S1 Industri Perjalanan Wisata \\ Fakultas Pariwisata UNUD
}

\begin{abstract}
Nowadays Bali has developed into a MICE tourist destination. Several events hav been a successfuly held in Bali. The event such of the ASEAN Summit and Climate Change Summit 2012, ASEAN Summit and the ASEAN Foreign Ministers Meeting. Behind the success of the international MICE events in Bali, there are the role of person who are competent to make it happen. Human resources in the area of MICE services have a very important role for MICE events took place. They are the one who hold the key to the success of the event. One of them is a representative of the hotel (venue) where the convention was held as a person in charge who will be contacted by the organizers to communicate all necessary purposes. The person in charge holds the key to the success of the hotel (venue) in providing the best service to convention delegates, and play crucial part of convincing the organizers to use hotel as a venue. This study was conducted to determine how the specification of the role of the person in charge in the organization of international MICE event.
\end{abstract}

Key words: Role of Person In Charge, Perception Delegation.

\section{PENDDAHULUAN}

Bali merupakan salah satu destinasi wisata yang diminati dunia. Saat ini Bali telah mengembangkan diri menjadi destinasi wisata MICE. Beberapa event konvensi internasional yang pernah sukses diselenggarakan di Bali seperti KTT ASEAN dan KTT Perubahan Iklim 2012, ASEAN Summit, dan ASEAN Foreign Minister Meeting.

Dibalik suksesnya penyelenggaraan event-event MICE internasional di Bali, terdapat orang-orang berkompeten yang menjadikan hal itu terwujud. Salah satunya adalah perwakilan hotel (venue) tempat konvensi diadakan sebagai person in charge yang akan dihubungi oleh pihak penyelenggara untuk mengkomunikasikan segala keperluan yang dibutuhkan. Penelitian ini dilakukan untuk mengetahui bagaimana peranan person in charge yang tersebut dalam penyelenggaraan event MICE dan bagaimana persepsi para peserta MICE terhadap pelayanan dan fasilitas yang mereka dapatkan selama mengikuti event MICE tersebut.

Mengacu pada latar belakang tersebut maka rumusan masalah dalam penelitian ini ada dua yaitu, bagaimana peranan person in charge dalam penyelenggaraan konvensi di The Westin Resort serta bagaimana persepsi delegasi konvensi terhadap pelayanan BICC The Westin Resort.

\section{METODE PENELITIAN}

Penelitian ini dilakukan di The Westin Resort yang berlokasi di kawasan BTDC Nusa Dua. The Westin Resort memiliki BICC (Bali International Convention Centre) sebagai venue konvensi internasional. Dalam penelitian ini terdapat dua variable yang digunakan yaitu, Peranan Person in Charge dan Persepsi Delegasi Konvensi. 
Teknik pengumpulan data dilakukan dengan dua cara, yaitu wawancara bebas terpimpin dan penyebaran kuesioner.

Pengambilan sampel menggunakan teknik Purposive Sampling. Responden yang dipilih untuk dijadikan sampel adalah peserta Coaltrans Asia Summit yang diselenggarakan dari tanggal 2-5 Juni 2013 yang bersedia untuk mengisi kuesioner. Jumlah peserta Coaltrans Asia Summit adalah 1200 orang. Jumlah peserta tersebut bisa dijadikan sebagai ukuran populasi sehingga untuk menentukan jumlah sampel dari populasi yang diketahui, digunakan rumus Slovin yaitu :

$n=\frac{N}{1+N e 2}$

dimana:

$\mathrm{n}=$ ukuran sampel

$\mathrm{N}=$ ukuran populasi

$\mathrm{e}=$ persen kelonggaran ketidaktelitian karena

kesalahan pengambilan sampel yang masih dapat ditolerir, yaitu $10 \%$

Dengan menggunakan rumus Slovin, maka nilai $\mathrm{n}$ yang dihasilkan adalah:

$n=\quad N$

$\overline{1+N e 2}=92,3=93$ orang (pembulatan)

Dari perhitungan tersebut, didapatkan jumlah responden sebanyak 93 orang dari populasi peserta Coaltrans Asia Summit sebanyak 1200 orang.

Teknik analisis data yang digunakan dalam penelitian ini adalah analisis deskriptif kualitatif. Sarana untuk mengukur persepsi delegasi konvensi terhadap peranan person in charge menggunakan kuesioner dengan pendekatan skala likert. Setiap responden diminta memberikan jawaban yang menunjukan tingkat sangat baik, baik, cukup baik, kurang baik dan sngat kurang baik. Masing-masing Jawaban diberi skor, yaitu:

Jawaban sangat baik diberi skor : 5

Jawaban baik diberi skor : 4

Jawaban cukup baik diberi skor : 3

Jawaban kurang baik diberi skor : 2

Jawaban sangat kurang baik diberi skor : 1

Untuk mengetahui tingkat intensitas persepsi maka dihitung nilainya dengan dapat dilihat dari rumus berikut:

Skor tertinggi - skor terendah $=$ rentang nilai Jumlah kategori

$$
\frac{5-1}{5}=0,8
$$

Berdasarkan rumus tersebut, maka masing-masing kategori memiliki rentang nilai sebesar 0,8. Dengan demikian maka dapat disusun kategori persepsi delegasi konvensi sebagai berikut:

Tabel 1

\section{Skala Sikap Delegasi Konvensi}

\begin{tabular}{|c|l|c|c|}
\hline \multicolumn{4}{|c|}{ Skala Sikap Delegasi Konvensi } \\
\hline No & \multicolumn{1}{|c|}{ Sikap } & Skor & Kategori \\
\hline 1 & Sangat Baik & 5 & $4,24-5,04$ \\
\hline 2 & Baik & 4 & $3,43-4,23$ \\
\hline 3 & Cukup Baik & 3 & $2,62-3,42$ \\
\hline 4 & Kurang Baik & 2 & $1,81-2,61$ \\
\hline 5 & $\begin{array}{l}\text { Sangat Kurang } \\
\text { Baik }\end{array}$ & 1 & $1,00-1,80$ \\
\hline
\end{tabular}

Sumber : Supranto (2006;99)

\section{HASIL DAN PEMBAHASAN}

\subsection{Peranan Person In Charge}

Person in Charge yang dimaksud disini adalah staff perwakilan BICC Westin yang bertanggung jawab terhadap pihak penyelenggara MICE. Pihak penyelenggara MICE dalam hal ini adalah Profesional Convention Organizer (PCO) seperti misalnya The Pacto, dll. Pihak PCO akan mengkomunikasikan segala keperluan kepada person in charge yang ditunjuk yang kemudian akan menyampaikan kepada pihak-pihak terkait di dalam manajemen BICC The Westin.

Secara garis besar peranan yang dilakukan ole person in charge tersebut terbagi kedalam 3 kelompok:

- Pre management diantaranya, mengikuti rapat pra konvensi dengan panitia penyelenggara dan perwakilan dari delegasi untuk membicarakan segala keperluan yang dibutuhkan, menyiapkan sambutan selamat datang sesuai dengan permintaan panitia penyelenggara, menyiapkan susunan acara sesuai dengan permintaan panitia penyelenggara dan sesuai dengan tujuan diselenggarakannya MICE tersebut, menyiapkan jadwal kegiatan yang sesuai bagi tiap orang peserta MICE, menyiapkan interpreter, $\mathrm{MC}$, pagar ayu, dll jika 
dibutuhkan, menyiapkan ruang rapat yang dibutuhkan dan sesuai permintaan panitia penyelenggara, menyiapkan segala fasilitas rapat yang dibutuhkan seperti, mengkonfirmasi makanan, minuman dan snack yang dipesan panitia penyelenggara ke dapur, menyiapkan special request jika ada, seperti misalnya ingin ada dokter yang standby, dll

- On site management diantaranya, final check, memastikan segala keperluan yang dibutuhkan dan dipesan oleh panitia penyelenggara telah siap, menangani registrasi peserta, menyelenggarakan acara pembukaan, menyelenggarakan fungtions : refreshment, lunch, and dinner, menangani acara pokok (presentasi dan diskusi) sesuai dengan kebutuhan : plenary maupun breakout session, menangani technical visit kalau perlu, menangani pameran kalau ada, dan menangani masalah-masalah yang bisa saja terjadi.

- Post management diantaranya, menangani post convention tour, sports, atau shopping sesuai pilihan, melakukan evaluasi terhadap pelaksanaan konvensi secara keseluruhan, menyebarkan form kritik dan saran kepada seluruh peserta konvensi sebagai bahan evaluasi, mengucapkan terima kasih kepada pihak yang mendukung, menyusun dan mengirim laporan pelaksanaan kepada pihak yang berkompeten, dalam hal ini Ketua BICC.

Dalam melakukan seluruh tugas dari pre management, onsite management hingga post management, Person In Charge ini akan mengkoordinasikan segala sesuatunya kepada divisi-divisi terkait kemudian berada dalam posisi sebagai pengawas, yang menjamin bahwa segala sesuatu tersedia dan berjalan sesuai rencana.

\subsection{Persepsi Delegasi Konvensi terhadap pelayanan BICC The Westin Resort}

Berikut ini akan diuraikan persepsi 93 orang delegasi konvensi yang mengikuti Coaltrans Asia Summit yang berlangsung di BICC The Westin dari tanggal 2-5 juni 2013. Persepsi tersebut meliputi persepsi terhadap pengaturan waktu dalam susunan acara konvensi, persepsi terhadap kebersihan ruang rapat, persepsi terhadap dekorasi room setups ruang rapat, persepsi terhadap kelengkapan fasilitas ruang rapat, persepsi terhadap kwalitas makanan, minuman dan snack yang disediakan dan persepsi terhadap acara sambutan selamat datang yang diselenggarakan.

\section{A. Persepsi Delegasi Konvensi terhadap Pengaturan Waktu dalam Susunan Acara Konvensi}

Adapun persepsi delegasi konvensi terhadap pengaturan waktu dalam susunan acara konvensi, dapat dilihat pada tabel berikut:

\section{Tabel 2}

Persepsi Delegasi Konvensi terhadap Pengaturan Waktu dalam Susunan Acara Konvensi

\begin{tabular}{|l|l|l|l|}
\hline No & \multicolumn{1}{|c|}{ Tanggapan } & $\begin{array}{c}\text { Jumlah } \\
\text { (orang) }\end{array}$ & $\begin{array}{c}\text { Persentase } \\
(\%)\end{array}$ \\
\hline 1 & Sangat Baik & 67 & 72 \\
\hline 2 & Baik & 19 & 21 \\
\hline 3 & Cukup & 6 & 6 \\
\hline 4 & Buruk & 1 & 1 \\
\hline 5 & Kurang Baik & - & \\
\hline \multicolumn{2}{|l}{ Jumlah Total } & 93 & 100 \\
\hline
\end{tabular}

Sumber : Hasil penelitian 2013

Berdasarkan Tabel di atas dapat dilihat persepsi delegasi konvensi terhadap pengaturan waktu dalam susunan acara konvensi yang disusun oleh Person In Charge sebanyak 67 orang menyatakan sangat baik (72\%), 19 orang menyatakan baik (21\%), 6 orang menyatakan cukup $(6 \%)$ dan 1 orang menyatakan buruk $(1 \%)$.

Penghitungan menurut skala likert dari 93 orang delegasi konvensi mengenai pengaturan waktu dalam susunan acara diperoleh skor dengan jumlah 431 dengan rata-rata 4,63. Kategori dengan nilai 4,63 masuk dalam kriteria sangat baik.

\section{B. Persepsi Delegasi Konvensi terhadap Kebersihan Ruang Rapat}


Adapun persepsi delegasi konvensi terhadap kebersihan ruang rapat dapat dilihat pada tabel berikut:

Tabel 3

Persepsi Delegasi Konvebsi terhadap Kebersihan Ruang Rapat

\begin{tabular}{|l|l|l|l|}
\hline No & Tanggapan & $\begin{array}{l}\text { Jumlah } \\
\text { (orang) }\end{array}$ & $\begin{array}{l}\text { Persentase } \\
(\%)\end{array}$ \\
\hline 1 & Sangat Baik & 54 & 58 \\
\hline 2 & Baik & 26 & 28 \\
\hline 3 & Cukup Baik & 13 & 14 \\
\hline 4 & Buruk & - & - \\
\hline 5 & Kurang Baik & - & - \\
\hline \multicolumn{2}{|l}{ Jumlah Total } & 93 & 100 \\
\hline
\end{tabular}

Sumber : Hasil penelitian 2013

Berdasarkan Tabel di atas dapat dilihat bahwa persepsi delegasi konvensi terhadap kebersihan ruang rapat sebanyak 54 orang menyatakan sangat baik (58\%), 26 orang menyatakan baik (28\%), dan13 orang menyatakan cukup baik (14\%). Perhitungan menurut skala likert dari 93 orang delegasi konvensi mengenai persepsinya terhadap kebersihan ruang rapat memperoleh skor 413 dengan rata-rata 4,44 . Kategori dengan nilai ini masuk dalam kriteria sangat baik.

\section{Persepsi Delegasi Konvensi terhadap Dekorasi Room Setups Ruang Rapat}

Adapun persepsi delegasi konvensi terhadap dekorasi dan room setups di ruangan rapat yang digunakan dapat dilihat pada tabel berikut:

Tabel 5

Persepsi Delegasi Konvensi terhadap Dekorasi dan Penataan Ruangan Rapat

\begin{tabular}{|l|l|l|l|}
\hline No & Tanggapan & $\begin{array}{l}\text { Jumlah } \\
\text { (orang) }\end{array}$ & $\begin{array}{l}\text { Persentase } \\
(\%)\end{array}$ \\
\hline 1 & Sangat Baik & 65 & 70 \\
\hline 2 & Baik & 25 & 27 \\
\hline 3 & Cukup & 2 & 2 \\
\hline 4 & Buruk & 1 & 1 \\
\hline 5 & Kurang Baik & - & - \\
\hline Jumlah Total & 93 & 100 \\
\hline
\end{tabular}

Sumber : Hasil penelitian 2013
Berdasarkan Tabel di atas dapat dilihat bahwa persepsi delegasi konvensi terhadap dekorasi rooms setups di ruang rapat yang digunakan sebanyak 65 orang menyatakan sangat baik $(70 \%), 25$ orang menyatakan baik $(27 \%), 2$ orang menyatakan cukup $(2 \%)$ dan 1 orang menyatakan buruk (1\%).

Perhitungan menurut skala likert, dari 93 orang delegasi konvensi mengenai persepsinya terhadap dekorasi rooms setups ruang rapat yang digunakan memperoleh skor 433 dengan ratarata 4,66. Nilai ini masuk dalam kategori sangat baik.

\section{Persepsi Delegasi Konvensi terhadap Kelengkapan Fasilitas Ruang Rapat yang disediakan BICC}

Adapun persepsi delegasi konvensi terhadap kelengkapan fasilitas ruang rapat yang disediakan dapat dilihat pada Tabel berikut:

\section{Tabel 4}

Persepsi Delegasi Konvebsi terhadap Kelengkapan Fasilitas Ruang Rapat

\begin{tabular}{|l|l|l|l|}
\hline No & Tanggapan & $\begin{array}{l}\text { Jumlah } \\
\text { (orang) }\end{array}$ & $\begin{array}{l}\text { Persentase } \\
(\%)\end{array}$ \\
\hline 1 & Sangat Baik & 66 & 70 \\
\hline 2 & Baik & 20 & 22 \\
\hline 3 & Cukup & 7 & 8 \\
\hline 4 & Buruk & - & \\
\hline 5 & Kurang Baik & - & - \\
\hline \multicolumn{2}{|l}{ Jumlah Total } & 93 & 100 \\
\hline
\end{tabular}

Sumber : Hasil penelitian 2013

Berdasarkan Tabel diatas dapat dilihat bahwa persepsi delegasi konvensi terhadap kelengkapan fasilitas ruang rapat sebanyak 66 orang menyatakan sangat baik (70\%), 20 orang menyatakan baik (22\%) dan 7 orang menyatakan cukup (8\%).

Perhitungan menurut skala likert dari 93 orang delegasi konvensi mengenai persepsinya terhadap kelengkapan fasilitas ruang rapat diperoleh skor dengan jumlah 431 dengan ratarata 4,63. Nilai dengan skor 4,63 masuk ke dalam kategori sangat baik.

E. Persepsi Delegasi Konvensi Terhadap Kwalitas Makanan, Minuman dan Snack yang Disediakan 
Adapun persepsi delegasi konvensi terhadap kwalitas makanan, minuman dan snack yang disediakan dapat dilihat pada Tabel berikut:

Tabel 6

Persepsi Delegasi Konvensi terhadap Kwalitas Makanan, Minuman dan Snack yang Disediakan

\begin{tabular}{|l|l|l|l|}
\hline No & Tanggapan & $\begin{array}{l}\text { Jumlah } \\
\text { (orang) }\end{array}$ & $\begin{array}{l}\text { Persentase } \\
(\%)\end{array}$ \\
\hline 1 & Sangat Baik & 71 & 76 \\
\hline 2 & Baik & 15 & 16 \\
\hline 3 & Cukup & 7 & 8 \\
\hline 4 & Buruk & - & \\
\hline 5 & Kurang Baik & - & - \\
\hline \multicolumn{2}{|l}{ Jumlah Total } & 93 & 100 \\
\hline
\end{tabular}

Sumber : Hasil penelitian 2013

Berdasarkan Tabel diatas dapat dilihat bahwa persepsi delegasi konvensi terhadap kwalitas makanan, minuman dan snack yang disediakan adalah sebanyak 71 orang menyatakan sangat baik $(76 \%), 15$ orang menyatakan baik $(16 \%)$ dan 7 orang menyatakan cukup $(8 \%)$. Perhitungan menurut skala likert dari 93 delegasi konvensi diperoleh skor dengan jumlah 436 dengan jumlah rata-rata 4,69. Skor tersebut masuk dalam kategori sangat baik.

\section{F. Persepsi Delegasi Konvensi terhadap Acara Sambutan Selamat Datang yang Diselenggarakan}

Adapun persepsi delegasi konvensi terhadap acara sambutan selamat datang yang diselenggarakan dapat dilihat pada Tabel berikut:

Tabel 7

Persepsi Delegasi Konvensi terhadap Acara Sambutan Selamat Datang yang Diselenggarakan

\begin{tabular}{|l|l|l|l|}
\hline No & Tanggapan & $\begin{array}{l}\text { Jumlah } \\
\text { (orang) }\end{array}$ & $\begin{array}{l}\text { Persentase } \\
(\%)\end{array}$ \\
\hline 1 & Sangat Baik & 54 & 58 \\
\hline 2 & Baik & 26 & 28 \\
\hline 3 & Cukup Baik & 13 & 14 \\
\hline 4 & Buruk & - & \\
\hline
\end{tabular}

\begin{tabular}{|l|l|l|l|}
\hline 5 & Kurang Baik & - & - \\
\hline Jumlah Total & 93 & 100 \\
\hline
\end{tabular}

Sumber : Hasil penelitian 2013

Berdasarkan Tabel diatas dapat dilihat bahwa persepsi delegasi konvensi terhadap acara sambutan selamat datang yang diselenggarakan bagi mereka sebanyak 54 orang menyatakan sangat baik (58\%), 26 orang menyatakan baik (28\%), dan 13 orang menyatakan cukup (14\%).

Perhitungan menurut skala likert, dari 93 orang delegasi konvensi persepsinya terhadap acara sambutan selamat datang yang diselenggarakan memperoleh skor 415 dengan rata-rata 4,46. Skor ini masuk dalam kategori sangat baik.

\section{SIMPULAN DAN SARAN Simpulan}

1. Secara garis besar peranan yang dilakukan oleh person in charge tersebut terbagi kedalam 3 kelompok:

a. Pre management, yaitu kegiatan persiapan awal penyelenggaraan konvensi, mulai dari mengikuti rapat pra konvensi dengan panitia penyelenggara, hingga persiapan segala kebutuhan konvensi yang dibutuhkan.

b.On site management, yaitu kegiatan selama konvensi berlangsung. final check, memastikan segala keperluan telah siap dan menangani segala hal yang dibutuhkan agar konvensi berjalan dengan sukses

c. Post management, yaitu kegiatan yang dilakukan setelah konvensi berakhir. Mulai dari menangani kegiatan post convention, melakukan evaluasi terhadap pelaksanaan konvensi secara keseluruhan, menyebarkan form kritik dan saran kepada seluruh peserta konvensi sebagai bahan evaluasi, hingga mengucapkan terima kasih kepada pihak-pihak terkait.

2. Persepsi 93 orang delegasi konvensi yang mengikuti Coaltrans Asia Summit yang berlangsung di BICC The Westin 2-5 juni 2013 yang meliputi persepsi terhadap pengaturan waktu dalam susunan acara konvensi, persepsi terhadap kebersihan ruang rapat, persepsi terhadap dekorasi room setups ruang rapat, persepsi terhadap 
kelengkapan fasilitas ruang rapat, persepsi terhadap kwalitas makanan, minuman dan snack yang disediakan dan persepsi terhadap acara sambutan selamat datang yang diselenggarakan masuk dalam kategori sangat baik.

3. Jika dipadu padankan, skor persepsi yang masuk dalam kategori sangat baik menujukan bahwa secara garis besar peranan yang dilakukan oleh Person In Charge dalam penyelenggaraan MICE di BICC The Westin Resort juga sangat baik. Walaupun masih ada sedikit yang menyatakan tidak puas merupakan kesalahan PCO.

\section{Saran}

Berdasarkan simpulan diatas, ada beberapa hal yang perlu disarankan yaitu:

1. Pencapaian yang sudah sangat baik saat ini bukan merupakan sebuah akhir namun merupakan standar awal yang harus ditingkatkan jika ingin bersaing sebagai venue MICE secara global.

2. Masih ada responden yang menyatakan tidak puas, meskipun dalam persentase yang sangat kecil, namun hal ini tetap harus ditindaklanjuti agar tingkat kepuasan delegasi konvensi terus meningkat.

\section{DAFTAR PUSTAKA}

Anonim, 2012. Data Kepariwisataan Provinsi Bali. Dinas Pariwisata Provinsi Bali.

Kusmayadi \& Endar. 2000. Metodologi Penelitian dalam Bidang Kepariwisataan. Jakarta: PT Gramedia Pustaka Utama

Pendit, Nyoman S. 1999. Wisata Konvensi "Potensi Gede Bisnis Besar". Jakarta: PT Gramedia Pustaka Utama

Slamet, Y. 1999. Analisis Kwantitatif untuk Data Sosial. Solo: Dabara Publisher

Yoeti, Oka A. 2000. Manajemen Wisata Konvensi. Jakarta: PT.Pertiga 